Portland State University

PDXScholar

7-22-1976

\title{
Verbal Strategies in Small Group Communication
}

Christine Marie Bunsick

Portland State University

Follow this and additional works at: https://pdxscholar.library.pdx.edu/open_access_etds

Part of the Communication Commons

Let us know how access to this document benefits you.

\section{Recommended Citation}

Bunsick, Christine Marie, "Verbal Strategies in Small Group Communication" (1976). Dissertations and Theses. Paper 2378.

https://doi.org/10.15760/etd.2376

This Thesis is brought to you for free and open access. It has been accepted for inclusion in Dissertations and Theses by an authorized administrator of PDXScholar. Please contact us if we can make this document more accessible: pdxscholar@pdx.edu. 
AN ABSTRACT OF THE THESIS OF Christine Marie Bunsick for the Master of Sclence In Speech Communication presented July 22, 1976.

Title: Verbal Strategies in Small Group Communication

APPROVED BY MEMBERS OF THE THESIS COMMITTEE:
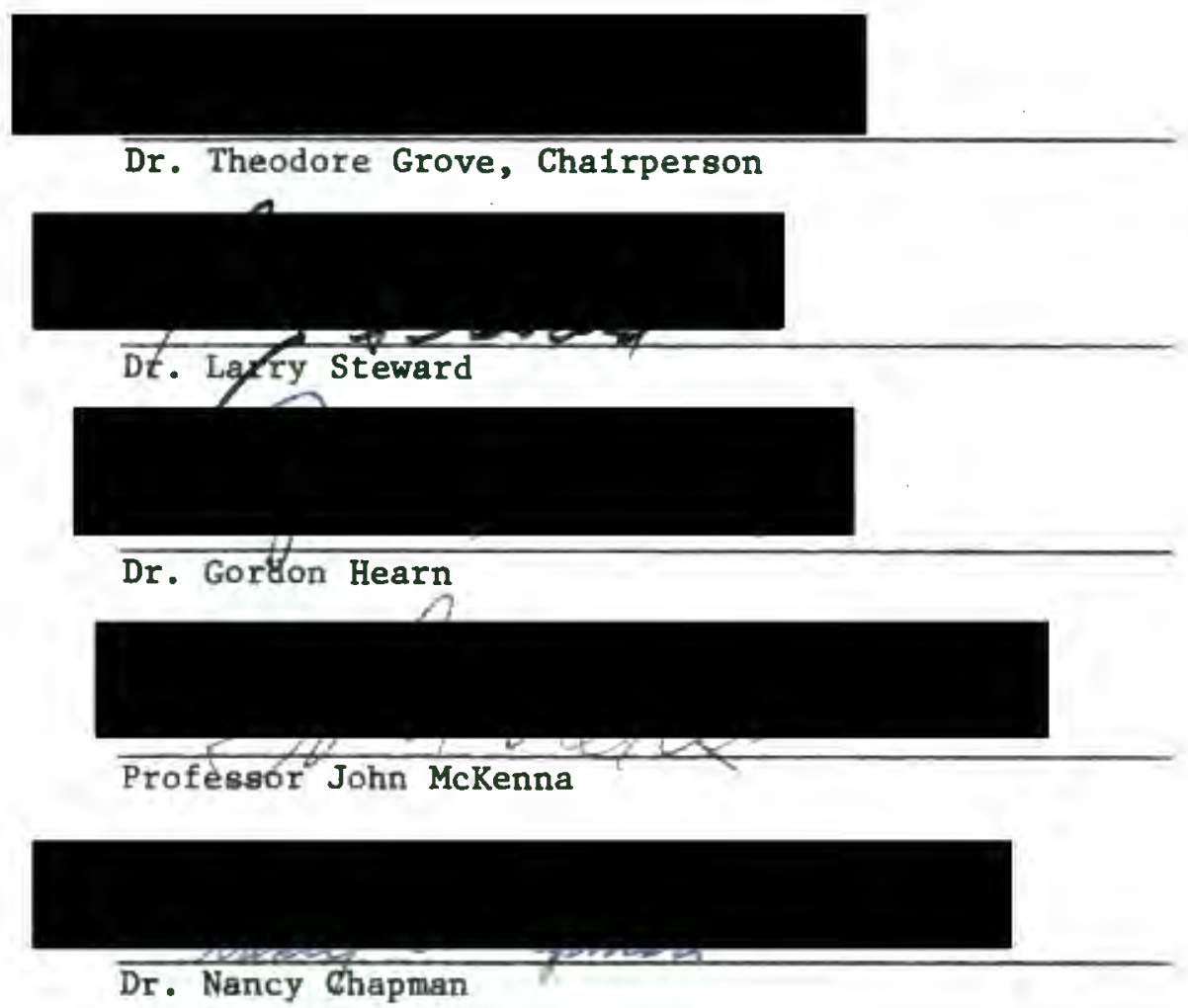

The purpose of this study is to investigate certain types of verbal communications people use in small task-oriented groups. The verbal communications analyzed are certain phrases a speaker may use prior to the central 1dea of the statement uttered. These verbal communications are referred to as "language tactics". 
Language tactics are defined here as specific phrases a speaker may use to excuse, justify, rationalize, or interpret for the listener(s) what the speaker is about to say before saying it. The purpose of this study is to look at language tactics as they are used by members of small task-oriented groups to answer two basic research questions:

1. Does the amount of previous interaction affect the use of language tactics by members of small taskorfented groups?

2. Does the type of task a small group 18 performing affect the use of language tactics by group members?

Twenty groups of students with membership ranging from four to six members per group participated in this experiment. Ten groups. consisted of Ss who had worked together as classroom project groups prior to participating in the study (01d Groups). The remaining half of the Ss consisted of new students in Speech Communication classes who had never worked together as groups prior to this study (New Groups).

Two different tasks with differing levels of ambiguity were utilized. Ss were directed to achieve consensus on a particular task. One-half of the old groups and one-half of the new groups were assigned a relatively ambiguous task situation $\left(\mathrm{T}_{\mathbf{A}}\right)$. The remaining old and new groups were assigned a relatively unambiguous task situation $\left(\mathrm{T}_{U}\right)$.

Data was collected by audio-tape recordings of group discussions. Transcripts of the discussions were prepared and content-analyzed by three judges for incldence of the occurrence of language tactics. The unit of analysis used in the content-analysis of the data was the 
phrase. Criterla was established by the experimenter for the scoring of phrases.

The proposal stated that there are two sets of conditions that Influence the probable use of language tact1cs by members of small task-orfented groups. Two research hypotheses were generated and tested. Both null hypotheses falled to be disconfirmed; thereby the research hypotheses were not supported by the data.

The study concludes with a review and critique of the study 1tself. Toplcs reviewed include the purpose of the study, the research questions the study proposed to answer, and the methods employed. Implications for future research are also discussed. 
VERBAL STRATEGIES IN SMALL GROUP COMMUNICATION

by

CHRISTINE MARIE BUNSICK

A thesis submitted in partial fulfillment of the requirements for the degree of

\author{
MASTER OF SCIENCE \\ In \\ SPEECH COMMUNICATION
}

Portland State UnIversity

1976 
TO THE OFFICE OF GRADUATE STUDIES AND RESEARCH:

The members of the Committee approve the thesis of

Chrlstine Marle Bunsick presented July 22, 1976.

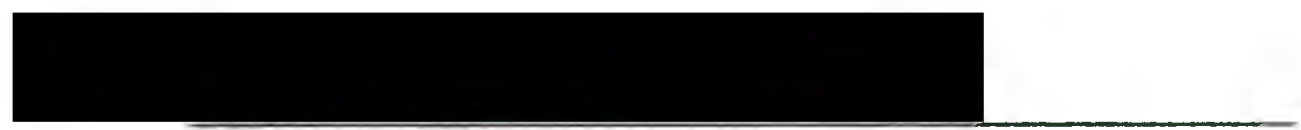

Dr. Theodore Grove, Cha1rperson

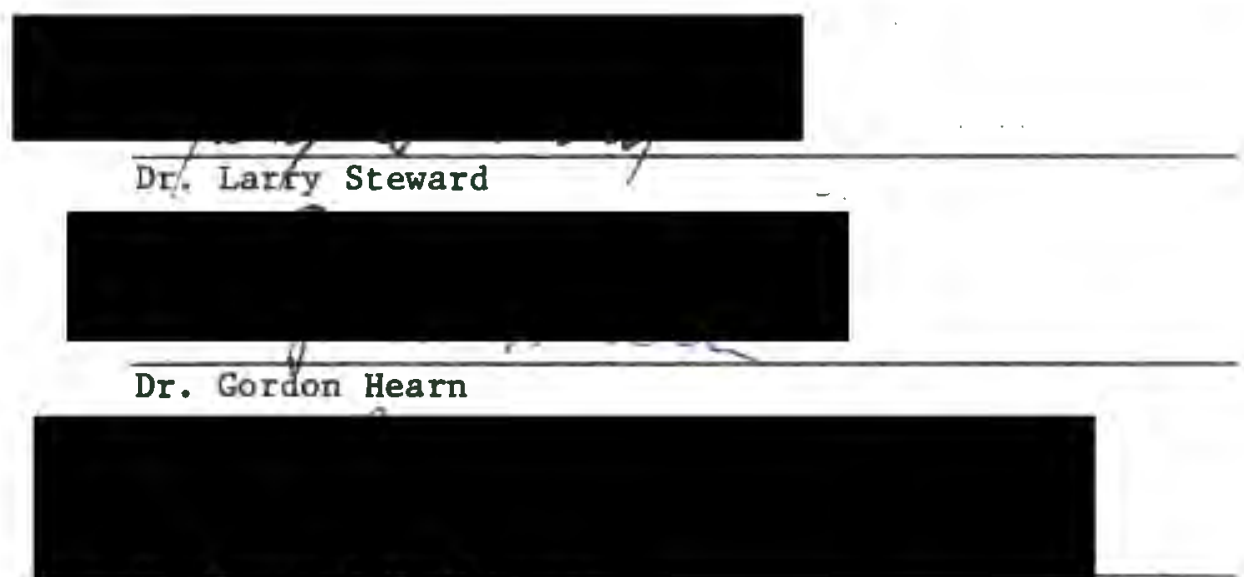

Professor John McKenna

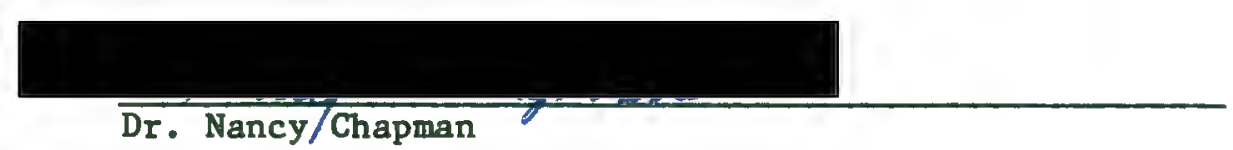

Dr. Nancy/Chapman

APPROVED :

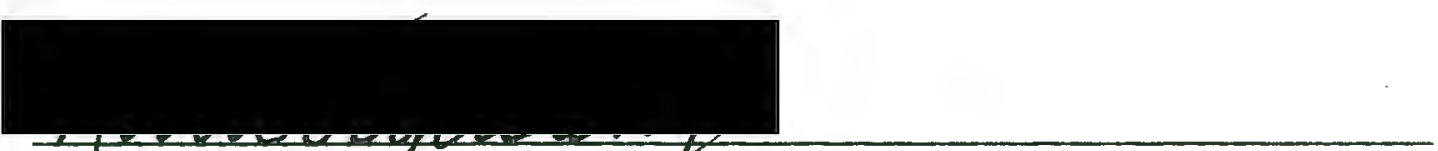

Dr. Robert Vogelsgng, Head, Department of Speech Communication

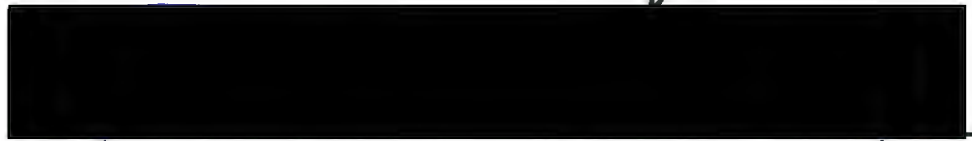

Dr. Richard B. Halley, Acting Dean, Graquate Studles and Research $\sqrt{1}$ 
TABLE OF CONTENTS

PAGE

ACKNOWLEDGMNTS . . . . . . . . . . . . . . . . . 111
LIST OF TABLES . . . . . . . . . . . . . . . . . vi

CHAPTER

I INTRODUCTION ........................ 1

II ASSUMPTIONS, THEORETICAL HYPOTHESES, AND RATIONALE . . 4

III RESEARCH HYPOTHESES . . . . . . . . . . . . 13

IV METHODOLOGY ................. . 17

V RESULTS .................. 23

VI DISCUSSIONS AND CONCLUSIONS . . . . . . . . 29

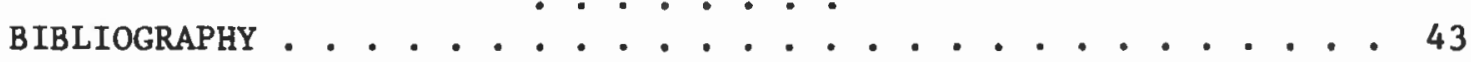

APPENDICES ............................. 45 


\section{ACKNOWLEDGEMENTS}

In this section, I should like to note several people who are very important to me and whose love, support, understanding and patience helped make this study possible.

In the first place, I'd like to thank my parents for instilling in me at a very early age a sense of appreciation and respect for education. Their encouragement and support was and will continue to be most appreciated and valued.

The person who deserves perhaps the most thanks is Mark, my dear friend, companion, and more who so enduringly put up with many hours of typing. His friendship and concern helped me survive many rough times here in Portlandtown.

Janet is thanked for her remarkable patience and understanding in the two years both of us shared an office. Her ability to take the time and listen especially as this study was in progress was most appreciated.

Dr. Ted Grove, my advisor, is mentloned because of all the help and guidance he provided throughout my graduate program. As deadlines approached, he very wisely set earlier deadlines for work to be accomp1ished. As a result, this study was completed on time.

Denny, Karla and Mark are thanked for their patience In coding the data. Jeanette and Elliot deserve a gold medal for all the work they did transcribing the data from tape to paper. Sharon, my typist, and her staff are thanked again for spending so much time correcting my mistakes on final copy. 
The faculty and staff of the Department of Speech Communications at Portland State University are also acknowledged and publicly thanked for their help, support and understanding they provided.

Finally, I'd like to mention my dog Calife. While he did no real work on this paper, his name is mentioned because while only a dog, he is nonetheless one of my best frtends. 


\section{LIST OF TABLES}

TABLE

PAGE

I Task Condittons . . . . . . . . . . . . . . 18

II Results of Inter-rater Rellabllity Study . . . . . . . 23

III Average Rating Per Group . . . . . . . . . . . 24

IV Breakdown by Group Type and Task Origin . . . . . . . . . 24

V Language Tacties Totals Per Treatment Condition ....... . 25

VI Analysts of Variance Table . . . . . . . . . . 26 
CHAPTER I

INTRODUCTION

"We11, I've never written a thesis before, so...": The preceeding phrase is one example of the subject of the present investigation: language tactics. Language tactics come in a varlety of shapes and forms; everyday life is a splendid place to observe their occurrence. Language tactics may serve a variety of purposes; we all use them so often that many times we are not consclous of their place in our everyday communications.

The above example represents a consclous use of a language tactic. Perhaps the author would like you the reader(s) to be aware of the fact that writing a paper of this nature is a new experience and wishes you to evaluate the paper with that in mind. This kind of language tactic is sometimes referred to as "special pleading". At other times, however, language tactics may be employed entirely outside of the speaker's awareness.

For example, a friend may invite me to play a game of tennis. My frlend knows I play tennis; my tennis racket hangs on a wall in the 11vIngroom. Obviously, my friend also plays tennis, or else the invitation to play would not have been extended. I reply: "I'm really not a very good tennis player, but I'll play."

At first, the only thing I remember telling my friend is that I accepted the invitation. Later, I can recall that I prefaced my acceptance of the invitation with the phrase "I'm really not a very good 
tennis player......".

Perhaps my reply served one of a number of different functions. For example, it might have mitigated the degree of personal humiliation that could attend defeat. It might have informed my friend of my awareness of my 1imftations in the game. It might have demonstrated that I recognize my friend's greater skfll on the court. It may have been a simple courtesy so my friend could select a more challenging competitor if desired. The list of functions potentially served by such a comment is seemingly endless.

The purpose of this study is to investigate certain types of verbal communications people use in small task-oriented groups. The verbal communications analyzed are certain phrases a speaker may use prior to the central idea of the statement uttered. These verbal communications are referred to as language tactics.

Language tactics are defined here as specific phrases a speaker may use to excuse, justify, ratfonalize, or interpret for the 11steners what the speaker is about to say before saying 1t. Examples of such language tactics might include phrases such as: "You're not going to 11ke this but..." (interpreting for the listener); or "I'm not really sure of this but...." (excusing the speaker); or "Since I've spent five years studying...." (referring to the speaker's credentials). Language tactics of this sort are readily observable in everyday life and it is the purpose of this study to look at language tactics as they are used by members of small task-oriented groups to answer two basic research questions:

1. Does amount of previous interaction affect the use of language tactics by members of small task-oriented groups? 
2. Does the type of task a small group $1 \mathrm{~s}$ performing affect the use of language tactics by group members?

Chapter Two defines language tactics and discusses the main assumptions, theoretical hypotheses, and rationales of the study. Chapter Three states the research hypotheses and Chapter Four describes the hypotheses-testing operations performed including methods of securing and analyzing data. Chapter FIve presents the results and Chapter S1x, the conclustons and discussion. 
CHAPTER II

ASSUMPTIONS, THEORETICAL HYPOTHESES AND RATIONALE

There are probably as many reasons for studying human communications as there are communicators. Since everything a person may say, think, belleve, and feel in response to other people or to the physical environment can in some way be interpreted as communication, the possibilities for research in the area of communfcation are as broad and diverse as 11fe Itself.

This study proposes to look at one very limited aspect of the communicative process, language tactics. The assumption here is that through an understanding of the parts, a greater awareness of the whole may be achieved. Experimental controls seem to be an approprlate means to investigate this aspect of communication, which here-to-fore has been studied only casually. Such limitation of focus which laboratory controls provide permit management of the complex factors that typlcally attend any naturalistic communicative event.

As stated in Chapter One, the purpose of this study is to investigate certain types of verbal communication people use in small taskorlented groups. The verbal communication analyzed are certain phrases a speaker may use prior to the central idea of the statement uttered. These verbal segments are referred to as "language tact1cs". Language tactics may include pre-interpretations ${ }^{1}$ of statements, pre-apologies ${ }^{2}$ by the speakers, softeners ${ }^{3}$, and opening 1 ines ${ }^{4}$. In essence, language tactics are specific phrases whose content consists of excuses, 
justifications, rationalizations, or interpretations which modify or quallfy the speakers subsequent message.

Eugene A. Weinste1n, for example, writes about "pre-interpretatlons" and "pre-apologies". His primary emphasis is that a communicator uses pre-interpretations and pre-apologies as well as post-Interpretations and name-droppling as means of getting others to do what the communicator wants them to do. Weinstein's main focus is the purpose of the interaction and the techniques the communicator uses to elicit desired responses from others. ${ }^{5}$ Some examples that Weinstein lists are: pre-interpretations: "Now be sure not to take this the wrong way. I don't want you to th1nk...."; pre-apologies: "I'm not quite sure of th1s... but...."; post-Interpretations: "Oh, that's not what I meant.."; name-dropping; "Back at Harvard....".6

Erving Goffman writes about "standard opening phrases" a communicator may use "In order to get away with obtruding the self upon the Interaction, elther as speaker or subject matter". 7 In other words, these are ways a speaker may enter a conversation. Some examples of standard opening phrases listed by Goffman Include: "The way I see 1t..", "In my opinion....", "Well I don't know anything about that sort of thing but I've always felt that....", "Well, If you ask me...." and "The same thing happened to me. I was....".8

Nierenberg and Calero describe "softeners" as "expressions Intended to Influence the 11steners in a positive manner".? Some examples and reasons. why a communicator may use softeners are listed by the authors in thelr book Meta-Talk. These Include: "You're going to like what I'm about to tell you" (preparing the listeners for what we believe w111 be good news for them); "It goes without saying" (attempting to get 
agreement before stating something); "What I'm about to tell you" (usually a disclosure that must be handled very carefully and usually involves the 1istener). 10

In this investigation, "language tactics" refers to pre-interpretations, pre-apologies, softeners, standard opening lines, and other phrases or statements uttered prior to the central idea of the subsequent statement and having the qualifying character of excusing, justifying, rationalizing, or interpreting in advance for the listener(s) what the speaker is about to say. A very limited amount of empirical research has been done to date dealing with any of the afore-mentioned tactics, and the writer found no reports of experimental investigations in this specific area.

The present study proceeds from some general assumptions. A communicator uses language tactics in a variety of communicative situations. Language tactics are probably more likely to be used in some situations than in others. A careful analysis and investigation could lead to identification of those contexts of most frequent use. This information, if obtained, would provide a basis for understanding this aspect of communicative behavior and the relationship of language tactics to other communication variables.

Scholars in several fields have focused on issues that relate directly to these assumptions. For example, George A. Miller writes that:

If we concentrate primarily on the words that people say, we are likely to think that the only purpose of language is to exchange information. That is one of its purposes, of course, but certainly not the only one. People exchange many things.11

Exchange is not a static entity. Rather, John Dewey writes, it is a 
process that creates new transactions and forms new historfes and affairs. Exchange is not an event that can be 1solated. ${ }^{12}$ George $C$. Homans looks at human behavior and interaction as an exchange process. His theory of social exchange, briefly summarized, states:

Human interaction Involves the exchange of goods and services, and the responses individuals in interaction elfcit from each other involve both rewards and costs.13

Implicit here 18 the 1dea that words do matter and can affect the outcome of interaction between people. When a communfator uses a language tactic, the message that is sent is explained verbally. According to Satir, In such a communication the communicator "Is denotatively speaking at the meta-communicative leve1". 14

Meta-communication, according to Ruesch and Bateson, is communication about comunication. ${ }^{15}$ It is a message within a message that can be conveyed efther verbally or nonverbally to the listener(s). Since this study deals with language tactics, only those meta-communications at the verbal level are considered.

Satir has described six different levels of abstraction for verbal meta-communications:

a. A person can label what kind of message he sent telling the recelver how serfously he wishes him to recelve it and how he should respond to 1 t.

b. He can say why he sent the message by referring to what the other did.

c. He can say why he sent the message by referring to what he thinks the other's wishes, feelings, intentions towards him are.

d. He can say why he sent the message by referring to a request made by the other.

e. He can say why he sent the message by referring to the kind of response he was trying to elfctt from the other.

f. He can say why he sent the message by referring to what he was trying to get the other to do or say or not do and not say. 16 
Language tactics may occur at any of the six levels of abstraction formulated by Satir. Although the levels Satir lists give some reasons why a speaker may employ meta-communications, the present focus is concerned only with the occurrence of such language tactics in the speaker's utterances.

Use of language tactics by communicators may provide some insight into the relationship between communicators. Jay Haley writes that "as people communicate, their relationship is defined as much by the qualifications of their messages as by the presence or absence of messages. 17

Barnlund writes that many messages contain both mainfest and latent meanings. ${ }^{18}$ An example may be a situation where identity is being challenged. Barnlund describes such a situation:

At one level, talk flows around a common interest or problem; at another, communication becomes a competition for status. Participants present their credentials and challenge those of others.... Communication becomes an occasion for asserting and validating personal identity rather than for testing what we know. Status reminder phrases such as "I've devoted years to this matter...", "I've had much more experfence....", or "You wouldn't be able to appreclate this...." are likely to invite reaction in kind. 19

From the above discussion, it is apparent that many variables may participate in creating the conditions in which language tactics are found to occur. The aim of this investigation is to begin the process of Identifying contexts which are conducive to the use of language tactics by communicators. Two theoretical hypotheses are proposed:

Theoretical

Hypothesis \#I: Communicators use more language tactics in connection with relatively new relationships than in relatively old relationships. A relatively new relationship is defined as one in which participants have had no or minimal previous contact. 
A relatively old relationship is defined as one in which participants have had moderate to a great deal of previous contact.

Rationale: Experiences in a variety of communfcation encounters supports the view that new people and/or new situations may create uncertainty. Through language and sense data, a way is found to relate to new others and gauge our stance in relation to them.

Grace de Laguna writes that "language, 11ke the tool, is primarily an instrument to be used for the accomplishment of objective ends. It provides an indirect way of dealing with things."20 Through the medium of language, new relationships can be formed, status' conferred, Identities validated. Patton and Giffin write that: "As you interact with another person, it is 11kely that you gain a general impression of 'where you stand' with him or her."21

Gross and Stone state that:

In every social situation, selves must be established, defined, and accepted by the parties. Every person in the company of others 1s, in a sense, obligated to bring his best self forward to meet the selves of others also presumably best-fitted to the occasion. 22

All the above suggests that people who have never interacted with each other w11l use more language tactics in thelr exchange than people who have interacted with one another for a relatively long perfod of time.

Theoretical

Hypothesis \#II: Communfcators' use of language tactics will vary with the nature of the task requiring interaction.

Rationale: It is easier to communicate with someone about a topic in which one 18 well-versed than it is to communicate about a topic where one has little knowledge. This applies to all areas of communication, 
from dyads to public address, from small groups to the symposiums.

In small groups, for example, the nature, or type, of task the group 18 engaged in will affect the communfcative behaviors of the particlpants. Roby and Lanzetta refer to the distinctive features of particular tasks which require certain group behaviors for adequate performance as 'critical demands'. 23

When communicators are engaged in small group discussion, for example, information is exchanged between members in order to complete the task the group is engaged in. Collins and Guetzkow write that in such a situation, the information must not merely be presented to be accepted by the group; it must be documented as well. ${ }^{24}$ Excuses, rationalizations, justifications or interpretations before statements may be one way of documenting information.

In this chapter, a definition of language tactics was given, major assumptions, theoretical hypotheses and rationales are listed. Chapter Three will focus on the research hypotheses. 


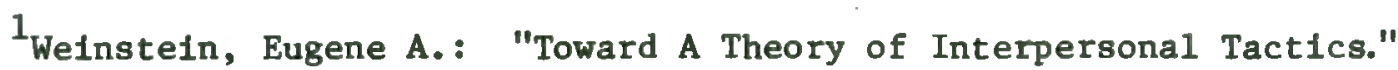
in Problems in Social Psychology edited by Carl W. Backman and Paul F. Secord; McGraw-Hil1 Book Company, New York, New York, 1966, p. 396.

2 Ibid; p. 396.

${ }^{3}$ Nierenberg, Gerald I. and Henry H. Calero: Meta-Talk: Guide to H1dden Meanings in Conversations, Trident Press, New York, New York, 1973, p. 33.

${ }^{4}$ Goffman, Erving: Encounters: Two Studies in the Sociology of Interaction, The Bobs-Merrill Company, Inc., Indianapolis, Indiana, 1961, pp. 50-51.

${ }^{5}$ Weinstein, Eugene A., op. c1t., pp. 394-398.

${ }^{6}$ Ib 1d; pp. 394-398.

${ }^{7}$ Goffman, Erving, ㅇ․ 소., pp. 50-51.

8 Ibid: p. 50-51.

${ }^{9}$ Nierenberg, Gerald I. and Henry H. Calero, op. c1t., p. 33.

${ }^{10}$ Ibid: p. 33.

${ }^{11}$ M11ler, George A.: "Nonverbal Communication." in Communication, Language, and Meaning: Psychological Perspectives, George A. Miller, Editor, Basic Books, Inc., New York, New York, 1973, pp. 240-241.

${ }^{12}$ Dewey, John: "Nature, Communication and Meaning." in The Human Dialogue: Perspectives on Communication, edited by Floyd W. Matson and Ashley Montagu, The Free Press, New York, 1967, p. 513.

${ }^{13}$ Goldberg, Alvin and Car1 E. Larson.: Group Communication; Prentice-Ha11, Inc., Englewood Cliffs, New Jersey, 1975, pp. 44-45.

${ }^{14}$ Satir, Virginia: "Communication: A Verbal and Nonverbal Process of Making Requests of the Recelver." In Messages: A Reader in Human Communication, Jean M. Civikly, editor, Random House, New York, New York, 1974, pp. 14-15.

${ }^{15}$ Ruesch, Jurgen, M.D. and Gregory Bateson: Communication: The Social Matrix of Psychiatry, W.W. Norton and Company, Inc., New York, New York, 1951, p. 209. 
${ }^{16}$ Satir, Virginia, op. cit., pp. 14-15.

17 Haley, Jay: "Establishment of an Interpersonal Relationship." in Interpersonal Communication: Basic Text and Reading, Bobby R. Patton and Kim Giffin, editors, Harper and Row Publishers, New York, New York, 1974, pp. 368-369.

18 Barnlund, Dean C.: "A Transactional Model of Communication." in Language Behavior: A Book of Readings, Johnnaye Akin, Alvin Goldberg, Gail Myers, Joseph Stewart, edftors, Moutin, The Hague, 1970, p. 52.

19 Barnlund, Dean C.: "Communications: The Context of Change." In Interpersonal Communications: Basic Text and Readings, Bobby R. Patton and Kim Giffin, editors, Harper and Row Publishers, New York, New York, 1974, pp. 31-32.

20 de Laguna, Grace Andrus: Speech: Its Function and Development; Indiana University Press, Bloomington, Indiana, 1963, p. 208.

${ }^{21}$ Patton, Bobby R. and Kim Giffin: Interpersonal Communication: Basic Text and Reading: Harper and Row Publishers, New York, New York, 1974, p. 344 .

${ }^{22}$ Gross, Edward and Gregory P. Stone: "Embarassment and the Analysis of Role Requirements." In Problems in Soclal Psychology, edited by Car1 W. Backman and Paul F. Secord, McGraw-H111 Book Company, New York, New York, 1966, p. 385.

${ }^{23}$ Roby, T.B. and J.T. Lanzetta: "Considerations in the Analysis of Group Tasks." Psychological Bulletin, 1958, pp. 88-101; p. 95.

${ }^{24}$ Collins, Barry E. and Harold Guetzkow: A Social Psychology of Group Process for Dectsion-Making, John Wiley and Sons, Inc., New York, New York, 1964, p. 30 . 


\section{CHAPTER III}

\section{RESEARCH HYPOTHESES}

The proposal here is that there are two sets of conditions that Influence the probable use of language tactics by members of small taskorfented groups. Each set of conditions consists of a combination of several situational variables.

The first set of conditions is assoclated with the amount of prior Interaction a group may have had: new groups as compared to old groups. It has been demonstrated that the set of conditions found in newly-formed groups consists of some of the following and other characteristics: no role relationships, no established status hlerarchy, few tested expectat1ons about acceptable behavior or unacceptable behavior, and no history of previous Interaction. 01d groups, on the other hand, have developed role relationshlps, established status hlerarchy, many tested expectations, and a long history of Interaction. Because of the vast differences between the two sets of conditions found in elther group, the communlcation patterns and styles are expected to differ.

Research Hypothesis 非: More language tactics will be used by communicators in new groups than by communtcators in old groups.

New groups are defined here as groups whose members have had no prior contact with each other before participating in the experiment. old groups are defined as groups that have been together as classroom project groups for ten weeks. 
The second set of conditions is associated with the type of task with which a group is engaged. Different tasks a group may perform have different inherent characteristics. For example, there are tasks with a complex number of answers; there are tasks requiring only one answer. Different tasks require different types of verbal behavior on the part of the group: some tasks require an extreme division of labor, other tasks may ut1lize subgrouping, st 111 others may require that the group work together at every step. There are tasks that have a single correct answer; there are other tasks for which there 1s no correct answer; st111 others where the answer is in series. Some tasks are completed only by performing several related sub-tasks; other tasks consist of a single phrase of work. There are some tasks where group members are given feedback as they work on the task, and others where they recelve none. Works by Cecil Gibb (1949), ${ }^{1}$ Carter and Nixon (1949), ${ }^{2}$ Carter, Haythorn, and Howel1 (1950), ${ }^{3}$ Katz, Blau, Brown and Strodtbeck (1957) ${ }^{4}$ and Mann and Mann $(1950)^{5}$ have demonstrated that different tasks produce different effects on group behavior and 1ts outcomes.

Research Hypothesis \#II: More language tactics will be used by communicators in a relatively uncertain task situation than by communicators in a relatively certain task situation.

A relatively uncertain task situation is defined as a task for which there is no correct answer or solution. A relatively certain task situation is defined as a task for which there is a correct answer or solution.

The present chapter has included research hypotheses and corresponding sets of conditions that define the terms of those hypotheses. 
Chapter Four describes the hypotheses-testing operations performed, including methods of securing and analyzing data. 


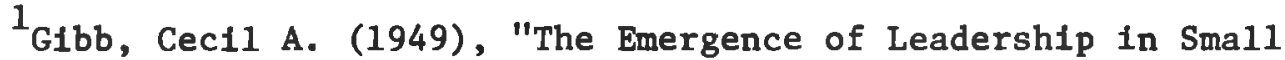
Temporary Groups of Men", unpublished Ph.D. dissertation (University of I11inols).

${ }^{2}$ Carter, Launor F., and Mary Nixon (1949), "An Investigation of the Relationship Between Four Criteria of Leadership Ability for Three Different Tasks", Journal of Psychology, 27, 245-261.

${ }^{3}$ Carter, Launor F., William Haythorn, and Margaret Howell (1950), "Further Investigation of the Criteria of Leadership", Journal of Abnormal and Soclal Psychology, 45, 350-58.

${ }^{4}$ Katz, Elihu, Peter M. Blau, Morton L. Brown, and F.L. Strodtbeck (1957), "Leadership Stability and Social Change: An Experiment with Sma11 Groups", Soc1ometry, 20, 36-50.

5 Mann, John H. and Carola H. Mann (1959), "The Importance of Group Task in Producing Group-Member Personal and Behavioral Changes", Human Relations, 12, 65-74. 
CHAPTER IV

METHODOLOGY

\section{Subjects}

Subjects (Ss) for this study were undergraduate students enrolled In speech communication classes at Portland State University Winter and Spring Quarters, 1976.

Twenty groups of students with membership ranging from four to six members per group particlpated in this experiment. The smaller and larger membership groups were scattered rather evenly across the several experimental treatments.

Ten groups were comprised of Ss who had been together as a group for ten weeks as classroom project groups (0ld Groups). These groups participated in the experiment during the last week of classes of Winter Quarter, 1976. The remaining half of the Ss were new students enrolled In speech communication classes, Spring Quarter, 1976 (New Groups). In this condition. (New Groups), group members did not know one another prior to being in the group and had not participated in the experiment the preceding term. This was the first time group members had been placed Into a group in the classroom.

Ss were told to achleve consensus as a requirement of task completion. This direction was given in order to ensure some participation by all members of the groups. Ss were Informed that the task would take them approximately thirty minutes to complete and that their discussions were betng tape-recorded but that no one was listening to the 
discussion as 1 t was in progress. Directions given to the groups are 11sted in Append1x $\# 1$.

Tasks

Two different tasks were employed in this study. One-half of the old groups and one-half of the new groups were presented with a relatively ambiguous task situation. This task involved ranking from "mostIlked" to "least-1iked" five characters in a short story (see Appendix \#2). Th1s task was represented as relatively amblguous because there was no correct solution and final ranking depended upon the various bellefs and values of group members.

The remaining old and new groups were presented a relatively unamb1guous task situation. This task was also a ranking task which involved deciding which 1 tems were most essentlal to survival (see Appen$\mathrm{d} 1 \mathrm{x}$ \#3). Th1s task represented a relatively unambiguous task situation because (1) It Involved one correct answer, (2) the problem was technical In nature, and (3) the task directions stated that a correct answer was ava1lable.

From the two levels of task variable and the two levels of the group varlable, four sets of experimental conditions were created, with five groups in each condition: Table I is a graphic representation of the task conditions.

TABLE I

TASK CONDITIONS

\begin{tabular}{l|c|c|}
\multicolumn{1}{c}{} & \multicolumn{1}{c}{ Old Groups } & \multicolumn{1}{c}{ New Groups } \\
\cline { 2 - 3 } Task Amb1guous & 5 groups & 5 groups \\
\hline Task Unambiguous & 5 groups & 5 groups \\
\hline
\end{tabular}




\section{Data Collection}

All twenty groups met in small rooms wired for tape-recording, so that audio tapes of the group discussions could be made without the presence of the tape recorder. Transcripts of the discussions were prepared and analyzed by three judges for incidence of language tactics.

\section{Methods of Analysis}

The untt of analysis used in the content analysis of the data was the phrase. The following criterla were established by the experimenter regarding the types of phrases to be scored:

1. Phrases must contaln at least one verb or verb form.

2. Phrases must contain the first person singular pronoun. Phrases contalning the first person plural pronoun are not to be scored.

3. Phrases must consist of an excuse, justification, rationalization or interpretation by the speaker for the listener(s) before the speaker utters the central idea of the statement. Three judges (two males, one female) scored Identical coples of the transcripts of the group discussions. Judges were instructed to score only those phrases meeting the criteria listed above. In light of the give-and-take nature of a small group discussion where a speaker may be Interrupted before having a chance to complete a statement, judges were also told to score phrases if they met the established criterla even though the sentences may not be complete. In the prepared transcripts, a change of speaker was denoted by a series of dots $(\ldots .$.$) . Judges were Instructed to look at statement between the se-$ ries of dots $(\ldots .$.$) . Appendix \# 4$ contains directions given to each judge. 
Training of the Judges

Judges met three times as a group before being given actual data. At the first meeting, the general purpose of the study was stated and the directions for coding were explained. The judges however, were not informed of the hypotheses during any point of the investigation. Two pages of transcripts from each of the twenty group discussions (forty pages) were given to each judge. These three forty-page sets of transcribed material were obtained by drawing two pages at random from each of the twenty discussions and scrambled. One set was given to each judge along with instructions to read the excerpts and score any phrases that met the criterla 11sted.

A second meeting was held two days later when the judges had completed all the excerpts. At the second meeting, all forty pages of the excerpts were reviewed together by the judges. Each judge explained his/her rationale for scoring particular phrases, and as a group, agreement was reached on what does or does not constitute a language tactic. Inftially, all three fudges were scoring an extremely large number of tactics. Apparently, all three were "reading 1 " too much. After this meeting, however, all were in agreement.

At the third meeting, judges reviewed and discussed the remaining excerpts. At the conclusion of this meeting, judges were given complete sets of transcripts from all twenty discussions, were reminded of the Instructions, and directed to content-analyze these data for language tactics.

Coples of the transcripts were labeled by number (Group I, Group II, etc.) so that the judges did not know which groups were old groups and which groups were new groups. The position in which a given 
discussion transcript appeared in the set of twenty such transcripts was determined by chance. The type of task was not included in the group label, but since there were only two tasks, the judges apparently could discern the task origin. However, since fudges were unaware of the hypotheses to be tested, this was not felt to be a problem.

Inter-Rater Rellability

Varfous methods for assessing inter-rater reliability were considered. The ideal material for this purpose would be exceedingly similar to the content of the experimental group discussions but not actually part of them. A search for adequately lengthy and unedited texts of actual discussions did not produce any satisfactory material. Another option considered was plays. This was disregarded because of differences in style and format from the actual data. Eventually, the experimenter created elght pages of group interaction. Four pages each centered around one of the two task sttuations described in the design of this investigation. Throughout these elght pages, various quant1ties of language tactics were incorporated into each page, ranging from one tactic per page to fifteen tactics per page.

The resulting eight-page booklet consisted of a scrambled order for pages with respect to frequency of tactics per page, thus avoiding any pattern in the booklet as a whole. Each judge was given a copy of this booklet and instructed to score the phrases as previously directed.

Due to a combination of factors, some of which included experimenter oversight, conflicting class schedules of the judges, and difficulty in obtaining appropriate material to measure inter-rater reliability, the data for the rellability study was obtained after the actual 
data were content-analyzed. However, this occurred prior to the dataanalyses for the hypotheses of the study. In other words, the data for the reliability study was collected after the main data of the study was obtained but was analyzed prior to the data analyses for the hypotheses. Inter-rater reliability is listed in Chapter $\mathrm{V}$. This chapter dealt with the methods of data collection and analysis utilized in this study, Chapter $V$ presents the results. 


\section{CHAPTER V}

\section{RESULTS}

In this chapter, the results are presented in the order in which various data analyses were performed.

The first analysis dealt with inter-rater rellability. Since the entire method of data analyses was dependent upon high levels of agreement between all three judges, this operation was performed first. The Pearson product moment correlation coefficient equation was employed in this operation. A t-test of significance for dependent means was computed to assess statistical significance of the resulting correlational co-efficients. The results are listed in Table II.

\section{TABLE II}

RESULTS OF INTER-RATER RELIABILITY STUDY

\begin{tabular}{|c|c|c|}
\hline & Judge \#1 & Judge \#2 \\
\hline Judge \#2 & $+.98^{*}$ & -- \\
\hline Judge $\|^{3} 3$ & $+.97^{*}$ & $+.96^{*}$ \\
\hline
\end{tabular}

Since a very high level of inter-rater relfability existed, the next step in the data analyses was to average the total number of language tactics per group across all ratings to obtain a single index of tactic frequency per group. This was accomplished by adding the three totals per group listed by each judge and dividing by three. These average ratings were used as data for subsequent analyses in this study 
and are 11sted in Table III.

TABLE III

AVERAGE RATING PER GROUP, $\mathrm{N}=20$

\begin{tabular}{ll}
\multicolumn{2}{c}{ Group } \\
Group & 1 \\
Group & 2 \\
Group & 3 \\
Group & 4 \\
Group & 5 \\
Group & 6 \\
Group & 7 \\
Group & 8 \\
Group & 9 \\
Group & 10 \\
Group & 11 \\
Group & 12 \\
Group & 13 \\
Group & 14 \\
Group & 15 \\
Group & 16 \\
Group & 17 \\
Group & 18 \\
Group & 19 \\
Group & 20
\end{tabular}

Average

14.666

11.333

14.666

2.666

12.666

20.000

11.000

4.666

15.333

5.666

12.666

15.333

13.000

5.000

7.666

5.333

0.000

6.666

7.666

4.666

The next step in the data analyses was to enter each average into the appropriate cell of a $2 \times 2$ fixed model analysis of varlance data table. Table IV lists this breakdown by group type (old group, new group) and task origin $\left[\left(\mathrm{T}_{A}\right)\right.$ relatively ambiguous, and $\left(\mathrm{T}_{U}\right)$ relatively unamb1guous] .

TABLE IV

BREAKDOWN BY GROUP TYPE AND TASK ORIGIN

\begin{tabular}{|c|c|c|}
\hline \multirow{7}{*}{$\mathrm{T}_{\mathrm{A}}$} & 01d Groups & New Groups \\
\hline & Group $3-14.666$ & Group $12-15.333$ \\
\hline & Group $6-20.000$ & Group $14-5.000$ \\
\hline & Group $7-11.000$ & Group $16-5.333$ \\
\hline & Group $8-4.666$ & Group $17-0.000$ \\
\hline & Group $9-15.333$ & Group $19-7.666$ \\
\hline & $=\overline{65.665}$ & $=\overline{33.332}$ \\
\hline
\end{tabular}


TABLE IV

(continued)

\begin{tabular}{|c|c|c|}
\hline \multirow{7}{*}{$\mathrm{T}_{\mathrm{U}}$} & 01d Groups & New Groups \\
\hline & Group $1-14.666$ & Group $11-12.666$ \\
\hline & Group $2-11.333$ & Group $13-13.000$ \\
\hline & Group $4-2.666$ & Group 15 - \\
\hline & Group $5-12.666$ & Group 18 - \\
\hline & Group 10- 5.666 & Group 20 - \\
\hline & TOTAL $=\overline{46.997}$ & $=\overline{44.664}$ \\
\hline
\end{tabular}

An analysis of varlance statistical procedure contains the assumption of homogenity of variance within the obtalned data across all treatment conditions. An f-max test for homogenity of variance was computed resulting in an index of 20.6 with 4 degrees of freedom for both the numerator and the denominator $(\mathrm{pq}, \mathrm{n}-1)$. This failed significance at $p .05$, satisfying the homogenity of variance requirement.

The main body of data for analyses of the experimental hypotheses consisted of language tactic scores for five groups in each of the four experimental treatment conditions $(\mathrm{N}=20)$. Table $\mathrm{V}$ 11sts total scores for each of the four five-group sets.

\section{TABLE V}

LANGUAGE TACTIC TOTALS PER TREATMENT CONDITION

$\begin{array}{lcccc} & \text { Old Groups } & \text { New Groups } & \text { Totals } \\ \mathrm{T}_{\mathrm{A}} & 65.665 & 33.332 & 98.997 \\ \mathrm{~T}_{\mathrm{U}} & \underline{46.997} & \underline{44.664} & 91.661 \\ \text { Totals } & 112.662 & 77.996 & \end{array}$

All analyses of variance procedures followed B.J. Winer. ${ }^{1}$ This data is presented in Table VI. 
TABLE VI

ANALYSIS OF VARIANCE TABLE

\begin{tabular}{rrrrl} 
& ss & df & ms & F \\
\hline A & 60.23 & 1 & 60.23 & $2.33 *$ \\
\hline B & 2.84 & 1 & 2.84 & $0.11 *$ \\
\hline AB & 44.85 & 1 & 44.85 & $1.74 *$ \\
\hline Error & 412.43 & 16 & 25.77 & \\
\hline Total & 520.35 & 19 & & \\
\hline \multicolumn{4}{c}{ * n.s. at alpha (Insert symbol) } & .05
\end{tabular}

The first research hypothesis, represented by factor $A$ in the analysis (see Table VI), stated that more language tactics will be used by communicators in new groups than by communfcators in old groups. The null hypothesis was not supported by this data. The total number of language tactics used by members of new groups in both task conditions equalled $77.996\left(\mathrm{~T}_{\mathrm{A}} 33.332+\mathrm{T}_{\mathrm{U}} 44.664\right)$. The total number of language tactics used by members of old groups in both task conditions equalled 112.662 ( $\mathrm{T}_{\mathrm{A}} 65.665+\mathrm{T}_{\mathrm{U}}$ 46.997). The members of old groups used 34.666 more language tact1cs than members of new groups.

The second research hypothesis, represented by factor $B$ in the analysis (see Table VI), stated that more language tactics will be used by communicators in a relatively uncertain task situation $\left(\mathrm{T}_{\mathrm{A}}\right)$ than by communicators in a relatively certain task situation $\left(T_{U}\right)$. The research hypothesis was not supported because the null hypothesis falled to be disconfirmed. In the relatively ambiguous task situation $\left(T_{A}\right)$, the total number of language tactics used by members of both the old groups and the new groups equalled 98.997 (65.665(old group) + 33.332 (new groups)). In the relatively unambiguous task situation $\left(T_{U}\right)$. 
a total of 91.661 language tactlcs were used (46.997(old groups) + 44.664 (new groups)). In this experimental condition, 7.336 more language tactics were used by members of both old and new groups in the relatively ambiguous task situation than by members in the relatively unambiguous task situation.

Overall, members of old groups used more language tactlcs than members of new groups in all experimental conditions. In the relatively unambiguous task situation, members of old groups used 2.333 more language tactics than members of new groups. In the relatively amblguous task situation, old group members used 32.333 more language tactics than members of new groups. Some plausible reasons for these differences w111 be discussed in the next chapter.

The final data analyses performed dealt with the interaction effects of the task and the group varlables, represented by factor $A B$ In Table VI. In checking the F-table at .95 with df $=1,16$ is 4.49 . Therefore, neither the main effects of A (task varlable) the main effects of $B$ (group variable), or the Interaction effects (AB) were signiflcant.

This chapter presented the results of the study. The test for inter-rater rellabllity produced a signiflcantly high correlation. Both research hypotheses falled to be supported by the obtalned data. Chapter VI w111 discuss the results of this study as well as implicatlons and suggestlons for further research. 
FOOTNOTES TO CHAPTER V

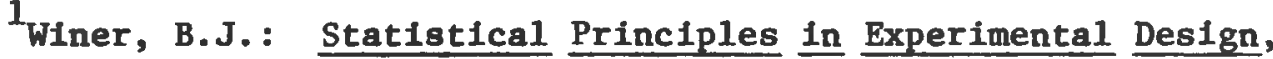
New York, McGraw-H111, 1962.
\end{abstract}


CHAPTER VI

DISCUSSIONS AND CONCLUSIONS

The focus of this chapter will be largely on the study itself: the positive points as well as the negative, the limitations as well as the potentlals for future research. The study will be reviewed and critiqued and occasionally apologized for with the insight only hindsight can give. Areas to be discussed w11l include the purpose of the study 1tself, the research questions it attempted to answer as well as the underlying rationale/theory of "language tactics". The research hypotheses and the methods will be critiqued and Implications for future research discussed. The format w111 be to 11 st each topic area and give the respective pros and cons. It is hoped that this approach will give the reader a more conclse means of judging the merits of this study.

THE PURPOSE

As stated at the beginning of this study, the purpose was to investigate certain types of verbal communications people use in small task-orfented groups. These verbal communicattons were labelled "language tactics" and defined as certain phrases a speaker may use prior to the central idea of the statement uttered. The aim of the investigation was to begin the process of identifying contexts that may be conductive to the use of language tactics by communicators. 
Advantages of the Purpose

1. The definftion of what constituted a "language tactfc" 11mited verbal communications analysed to those occurring prior to the central idea of the statement. This served to establish a manageable hold on the variety of communications exchanged between members of small task-oriented groups.

2. By focusing only on the occurrence of language tactics in small task-oriented groups, the sticky question of motive was not dealt with.

3. In restricting the study to two variables (group and task) a degree of control was established so that four possible contexts of the use of language tactics could be explored.

\section{Disadvantages of the Purpose}

1. While the definition of what constitutes a "language tactic" was established and held to, this definition was perhaps too all-encompassing. In retrospect, excuses and fustifications do not appear to belong in the same category as name-dropping and spectal pleading.

2. The motive for the use of a language tactic must be studied. A mere count of the occurrence of language tactics tells nothing about the climate of the small task-orfented group.

3. The 1imit of the study was perhaps too severe, Ideally, there should have been three group variables as opposed to two. Utilizing groups that perhaps had been together for five weeks (half as long as the old groups) would perhaps result in a better understanding of the development of language tactic usage by group members. A laboratory setting also has definfte drawbacks to encouraging "normal" communications. 
RESEARCH QUESTIONS

Two basic research questions were asked. These dealt with (1) the amount of previous interaction group members may have had with each other and (2) the type of task a group was performing. The question asked if efther of these variables (amount of Interaction and type of task) affected the use of language tactics by group members.

\section{Advantages of the Research Questions}

1. Limiting the study to small task-orfented groups established a degree of control and a limit of focus on the study.

2. Utilizing only two tasks having relatively different degrees of ambiguity in the task origin served to confine communications among group members to a set topic, thereby making comparisons between groups possible.

\section{Disadvantages of the Research Questions}

1. The verbal exchanges between group members was the only aspect studied. The expectations of group members at the interpersonal level was not dealt with but merely assumed - 1.e. It was simply assumed that group members brought different expectations to the group, but this was never verified.

2. The tasks themselves had no direct relationship to the lives of any group members. Perhaps group members performed the tasks merely because they were required to do so.

\section{THEORETICAL ASSUMPTIONS}

The theoretical assumptions for this study came largely from the works of Weinstein, Goffman, Satir, Reusch and Bateson, and Nierenberg 
and Calero. All these authors elther write directly about or refer to one or more aspects of what the study defines as "language tactics". The major advantage of these theoretical assumptions lies in the fact that all of the afore-mentioned researchers acknowledge the existence of what has been defined here as "language tactics" but cite to empirical re- . search relating to the occurrence of this phenomena. This study developed from an Interest on the part of the author pertaining to the phenomena of interpreting, justifying, rationalizing or excusing statements. The major disadvantage of the theoretical assumptions lies in the fact that most, if not all, of the authors cited refer to the possible motives a speaker may have that Initlates the use of a language tactic as defined by this study. This study, however, deliberately avolded the motivational aspect and concentrated solely on the contextual. That 1s, of 1tself, an Inherent drawback. The author now realizes that motives must be studied in order to gain a better understanding of the contextual variables.

THEORETICAL HYPOTHESES AND RATIONALES

Two theoretical hypotheses were developed and rationales for each discussed. In retrospect, several inherent discrepancles existed between both theoretical hypotheses and thelr respective rationales.

The first theoretical hypothesis stated that communfcators would use more language tactics in relatively new relationships then in relatively old relationships. Relatively old and new relationships were arbitrarily defined by the experimenter. The primary. weakness of the rationale was the speculation upon individual strategles and motives and the neglect of the group and situational variables. Perhaps a more 
logical rationalization might be Erving Goffman's discussion of how a "working consensus" is achieved and maintained within the small group. By concentrating on the group as a whole Instead of Individual communicators with the group, more congruency between the theoretical hypothesis, the rationalization, and the study itself might have been achieved.

The second theoretical hypothesis stated that communicators use of language tactics would vary with the nature of the task requiring interaction. The major weakness of this hypothesis and rationale is twofold:

1. The theoretical hypothesis as stated incorrectly assumes that the task situation is the only situation in which people communicate with each other. Varfous communication experiences tells one that such is not the case.

2. The theoretical hypothesis, as stated, assumes that language tactics are a task, and not a social phenomena.

While the use of language tactics may be influenced by a task situation, the task situation is not necessarily the primary stimulant for the implementation of language tactics by communicators. The first theoretical hypothesis, for example, lists other reasons why communicators may use language tactics.

In summary then, the major weaknesses of both theoretical hypotheses lies in the discrepancles between the hypotheses themselves and the supporting rationales. In retrospect, the author is aware of these incongruencies, which were not readily apparent at the time the study was designed and implemented. If these discrepancies had been noticed ear11er, the study might have been approached differently. In all likelihood, the major emphasis of the study would have been that of language tactics as a purely social phenomena which may or may not occur in the 
building and maintaining of a "working consensus". The second theoretical hypothesis would have been disregarded and the phenomena of language tactic usage as related to task origin would have been suggested as an area of further study, and not dealt with at all in the study itself at such an early point.

\section{RESEARCH HYPOTHESES AND RESULTS}

Two research hypotheses were established, but both null hypotheses falled to be disproved, thus invalidating the research hypotheses. The first research hypothesis stated that communicators in new groups would use more language tactics than communicators in old groups. The assumption was that since new groups had no role relationships or status hierarchies, few tested expectations about acceptable behaviors and no previous interaction, language tactics would be utilized more by members in the forming staging to ascertain all group norms. Perhaps the fact that old groups used more language tactics indicates that group members were aware of the group norms and structure and were acknowledging that structure in communications with other members. Since members of the new groups were not sure if they would ever be in the same group again they were not as concerned about their communications with other members. Again, the phenomena/perspectives motives would have had to be examined.

The second research hypothesis stated that more language tactics would be used by communicators in a relatively ambiguous task situation than by communicators in a relatively unambiguous task situation. The assumption was that different types of tasks produce different effects on group behavior. In this study, however, no real difference existed 
in the amount of language tactics used by group members in the two different task situations employed. Perhaps the fault lies in the tasks themselves, or perhaps other group varlables such as those discussed in reference to the first research hypothesis come into play. Perhaps too the tasks were too slmiliar in format - 1.e. both solutions required ranking, there was no need for a division of labor, and both consisted of a single phase. The outcomes of both tasks had no effects whatsoever on the lives of any group members nor did either task have any real dfrect relationship to past life experfences of group members.

\section{METHODS}

A laboratory situation does not lend 1tself well to real-1ife communication patterns. When group members are placed in small rooms and informed that their discussion is being tape-recorded, communication patterns may be altered. The only advantage to the laboratory method as opposed to field observation lies in the degree of control the experimentor can place on the study.

Ideally, the field observation method would be the best. In such a situation, communicators may not be aware that their verbal discourses are being studied and the communfcators would be responding to real situations as opposed to laboratory tasks. Perhaps motives would be easier to discern. For example, consider the job interview. In such a situation, the applicant would most likely be very careful in the selection of words and phrases in response to questions asked by the interviewer. In all likelihood, the applicant's responses would be influenced by the desire to secure employment, possibly causing the person to use more "language tactics" in responding to the interviewer's questions. Another 
interesting place to document the occurence of language tactics may be meetings conducted by various university departments, especially those meetings which deal specifically with funding. The assumption here is that an observer would record a much higher incidence of the use of language tactics at such a meeting, where very definite motives exist, than at a bridge club meeting, which is primarily social.

Rather than merely recording the number of language tactics uttered by the group as a whole, another approach might be to 1 ist all members of a group and then record the number of language tactics each uses in reference to other group members. Perhaps a pattern of deference can thereby be ascertained and the relative status of each member gauged.

To conclude the discussion of methods, a field study would have been a better place to do a study of this nature. The laboratory situation restricts and alters normal communication patterns, if not by the physical environment 1tself (a small closed room), then most likely by the knowledge group members have that their discussion is being tape recorded.

\section{SUBJECTS}

Middle-class college undergraduates may not be the best subjects to be used in a study of this nature. College students are, for the most part, full-time students whose main concern is getting through college and earning a degree. Work experience for the most part is limited to afterschool fobs and summer-time employment. In terms of age, soctal class, and educational background the similarity is astounding. Contact with the "real world" Is minimal. The question raised here 1s "can data drawn from such a pool be applicable to the rest of the culture?". This is a 
question that any researcher who uses college students as subjects must consider.

Subjects in this study particlpated for one of two reasons: (1) their instructor told them they had to, and (2) they were given the Incentive of extra project credit for particlpating. These two reasons no doubt had some effect on the resulting discussions. No groups particlpated because they expressed any real concern for any of the tasks themselves. The outcome of the discussions in no way affected them directly with the exception of the extra profect credit. In all 11kel1hood, all subjects probably particlpated in the experiment because there was some outside force 1nvolved. It 1s doubtful that any subjects ego or self-concept was called on the line and in all likelthood there are no after-effects to the tasks. Perhaps subjects looked at the task as simply another requirement to be done and proceeded from there. Whatever the case, there was probably no strong motivational force involved in the completion of elther task. There were no Immediate or long-term goals to be realized by performing the tasks, so perhaps involvement in the tasks was not as keen as it may have been given another situation.

\section{TASKS}

Two different tasks were ut1lized in this study. The tasks were chosen on the basis of relative ambiguity of the task origin. The relatively unambiguous task situation (NASA-Lost on the Moon) was Initially difficult in concept for group members. The ambiguous task situation (Castaways) offered no positive characters to choose from and therefore It may have been better to chose a different task such as the KIdney Machine Problem. Nelther task (NASA and Castaways) demanded much 
involvement on the part of all group members. Language tactics recorded may have been mere instances of politeness. Nelther task directly related to group members elther as a group or individuals.

In summary, while the tasks had the potential for generating discussion among group members, perhaps more relevant tasks could have been selected.

\section{GROUPS}

Twenty groups ranging in membership from four to six members per group participated in the study. One half of the groups (ten groups) had been together all of Winter Quarter, 1976, as classroom project groups. In these groups, conversation was constant, members interrupted each other frequently, and two or more members occasionally spoke at the same time. There were very few periods of silence on the tape-recordings of their discussions and these groups usually had to be told to stop their discussions when time ran out.

The remaining ten groups consisted of individuals who had never been together with other group members prior to participating in this experiment. In this situation, there were long perfods of silence on the audio tapes, generally only one person spoke at a time, and speakers had a tendency to trall off before completing a sentence. In old groups, however', the speaker would most 1ikely be interrupted. Perhaps this difference in the amount of speech uttered contributed to the difference in the number of language tactics uttered by members of old and new groups.

IMPLICATIONS FOR FUTURE RESEARCH

While limited in scope (only the occurrence of language tactics 
was documented), in subjects (only college students were used as subjects), and in methods (only the laboratory approach was utilized), this study nonetheless carries implications for future research into the area of human communications.

While exploratory in nature and in general a fatlure in terms of hypotheses-testing, this study nonetheless is a beginning step in the study of communication as a process as opposed to a static entity. The process of communication is a many faceted one, with as many variables present as the physical and psychological environments allow. By looking at verbal communications within a specific context, perhaps inner environments may be better understood.

All too often in research, the process is overlooked. In small group research for example, much is written about group norms and status hierarchies. Little, if anything at all, is written about how these norms and hierarchies come into being. A student of communications may be left with the understanding that these variables do exist but how they actually come into being is not explained or even guessed at. Perhaps verbal communications, similar to language tactics, create the norms and the hierarchies.

Thayer writes that "taking the process for granted obscures those elements which might otherwise lead to more fruitful explanations of the obvious."1 Future research; then, might concentrate on how language is employed in interpersonal interactions as part of the means of understanding the process.

The following recommendation was drafted by the 1968 New Orleans Conference on Research and Instructional Development. It merits mention here because so little has been done even elght years after the conference 
with respect to studying communication as a process and not as a static entity.

Recommendation 29: The conferees encourage research emphasizing the interactive, on-going, process nature of speech communication.

Research to date in speech communication often has oversimplified the multi-dimensional, real-1ife communicative process by taking a static view of communicative behaviors. Studies most of ten have been restricted to the consequences of single messages. Too few studies have focused on interactions, with detalled and specific examination of moment-to-moment, sequential, contingent behavior.

Greater emphasis on intensive analysis of process should lead to:

(a): Consideration of new and significant research questions regarding such matters as strategies and constraints in message choice.

(b): Concern with a wider range of communicative environments and their relationships, extending from dyadic communication to small-group deliberations to polarized mass communication, and:

(c): Study of previously unformulated speech functions beyond the traditional informative-persuasive-entertaining tri1ogy, such as "rapport-establishing" and "territory-cla1ming". 2

While the present study by no means approaches any of the abovestated recommendations, the author was nonetheless comforted to learn that research into the process (of which spoken language is a part) is a type of research that is encouraged in the field. Of course, the chances of fallure in such a study are much greater. Nonetheless, it is by fafling that one learns. Just as one learns from one's own mistakes, so too can others.

Future research dealing with language tactics might explore motives and expectations using the critical incident approach. Such an investigaion may reveal how personal goals are pursued in any interaction as well as give insight into the motives various communicators may have in a specific situation. Another area might be that of interaction between communicators of different established statuses. It is this researcher's guess that high status communicators will use 
more language tactics in addressing lower status communfators than lower status communicators will use in addressing communfcators of higher status. The potential for fruitful study of language tactics/seems 1im1tless.

\section{CONCLUSION}

While no research hypotheses were supported in this study, the redeeming factor may be that this study represents the first attempt to emiplrically study and define "language tactics". More research into this area is definitely warranted to understand this one aspect of our communfcative behavior. Future research may conclude that language tactics are definfte strategles employed to consciously accomplish personal goals, simply filler words, or mere courtesy terms. Language tactics may be all or none of these. Only the future will tell. Perhaps, too, the language tactic is a mere phenomena of spoken English. A study of the conversation styles of other cultures and languages might prove interesting.

This study represents one person's attempt to emplrically define and study "language tactics". In this study it was found that the variables of group and task origin had minimal effect upon the use of language tactics by communicators. Perhaps future research will yield different results. 
1Thayer, Leo: "On Theory-Building in Communication: Some Persistent Obstacles". In Language Behavior: A Book of Readings in Communication, edited by Johnnye Akin, Alvin Goldberg, Ga11 Myers, Joseph Stewart, Mouton, The Hague, Paris, 1970, p. 37.

${ }^{2}$ Kibler, Robert J. and Barker, Larry L. (editors): Conceptual Frontiers in Speech Communication: Report of the New Orleans Conference on Research and Instructional Development, New Orleans, Louisiana, Febbruary 11 - 16, 1968, Speech Association of America, Statler-Hilton Hote1, New York, New York, 1969, p. 35. 


\section{BIBLIOGRAPHY}

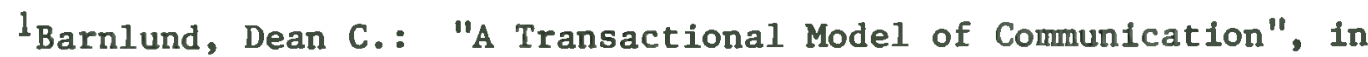
Language Behavior: A Book of Readings, Johnnye Akin, Alvin Goldberg, Ga11 Myers, Joseph Stewart, editors, Moutin, The Hague, 1970.

2Barnlund, Dean C.: "Communications: The Context of Change", in Interpersonal Communications: Basic Text and Readings, Bobby R. Patton and K1m Griffin, editors, Harper and Row Publishers, New York, New York, 1974.

${ }^{3}$ Carter, Launor F., and Mary Nixon (1949), "An Investigation of the Relationship between Four Criteria of Leadership Ability for Three Different Tasks", Journal of Psychology, 27, 245-261.

${ }^{4}$ Carter, Launor F., William Haythorn, and Margaret Howell (1950), "Futher Investigation of the Criteria of Leadership", Journal of Abnormal and Social Psychology, 45, 350-58.

${ }^{5}$ Collins, Barry E. and Harold Guetzkow: A Social Psychology of Group Process for Decision-Making, John Wiley and Sons, Inc., New York, New York 1964.

6de Laguna, Grace Andrus: Speech: Its Function and Development; Indiana University Press, Bloomington, Indiana, 1963.

7Dewey, John: "Nature, Communication and Meaning" in The Human Dialogue: Perspectives on Communication, edited by Floyd W. Matson and Ashly Montagu, The Free Press, New York, 1967.

${ }^{8} \mathrm{Gibb}$, Cec1l A. (1949), "The Emergence of Leadersh1p in Sma11 Temporary Groups of Men", unpublished PhD dissertation (University of Illinols).

${ }^{9}$ Goffman, Erving: Encounters: Two Studies in the Soclology of Interaction, The Bobs-Merrill Company, Inc., Indianapolis, Indiana, 1961.

${ }^{10}$ Goldberg, Alvin and Carl E. Larson: Group Communication; PrenticeHall, Inc., Englewood Cliffs, New Jersey, 1975.

${ }^{11}$ Gross, Edward and Gregory P. Stone: "Embarassment and the Analysis of Role Requirements", in Problems in Social Psychology, edited by Carl W. Backman and Paul F. Secord, McGraw-Hill Book Company, New York, New York, 1966.

${ }^{12}$ Haley, Jay: "Establishment of an Interpersonal Relationship", in Interpersonal Communication: Basic Text and Reading, Bobby R. Patton and Kim Griffin, editors, Harper and Row Publishers, New York, New York, 1974. 
13 Katz, E11hu, Peter M. Blau, Morton L. Brown, and F.L. Strodtbeck (1957), "Leadership Stabllity and Social Change: An Experiment with Small Groups", Soc1ometry, 20, 36-50.

$14 \mathrm{~K} 1 \mathrm{bler}$, Robert J. and Barker, Larry L. (editors): Conceptual Frontlers in Speech Communication: Report of the New Orleans Conference on Research and Instructional Development, New Orleans, Loulslana, February 11-16, 1968, Speech Assoclation of Amer1ca, Statler-Hilton Hotel, New York, New York, 1969.

15 Mann, John H. and Carola H. Mann (1959), "The Importance of Group 'lask In Producing Group-Member Personal and Behavioral Changes", Human Relations, 12, 65-74.

16 M1ller, George A.: "Nonverbal Communication", in Communication, Language, and Meaning: Psychologlcal Perspectives, George A. Miller, Editor, Basic Books, Inc., New York, New York, 1973.

17Nlerenberg, Gerald I. and Henry H. Calero: Meta-Talk: Guide to Hidden Meanings in Conversations, Trident Press, New York, New York, 1973.

18 Patton, Bobby R. and KIm Griffin: Interpersonal Communication: Basic Text and Reading:, Harper and Row Publishers, New York, New York, 1974.

19 Roby, T.B. and J.T. Lanzetta: "Considerations in the Analysis of Group Tasks." Psychological Bulletin, 1958, pp. 88-101; p. 95.

${ }^{20}$ Ruesch, Jurgen, M.D. and Gregory Bateson: Communication: The Soclal Matrix of Psychlatry, W.W. Norton and Company, Inc., New York, New York, 1951.

${ }^{21}$ Satir, Virginia: "Communication: A Verbal and Nonverbal Process of Making Requests of the Receiver", in Messages: A Reader in Human Communication Jean M. Civikly, editor, Random House, New York, New York, 1974.

22 Thayer, Leo: "On Theory-Building in Communication: Some Persistent Obstacles", in Language Behavior: A Book of Readings in Communicat1on, edited by Johnnye AkIn, Alvin Goldbert, Gail Myers, Joseph Stewart, Mouton, The Hague, Paris, 1970.

23Weinstein, Eugene A.: "Toward a Theory of Interpersonal Tactics" in Problems in Social Psychology, edtted by Car1 W. Backman and Paul F. Secord; McGraw-Hill Book Company, New York, New York, 1966.

24 Winer, B.J.: Statistical Principles in Experimental Design, New York, McGraw-Hil1, 1962. 
APPENDIX A

DIRECTIONS GIVEN TO Ss

Before going over the directions for this experiment, I would like to take the time now to personally thank all of you for taking some of your time to participate in this experiment. I will try to get my results back to you by the end of this term; 1f that is 1mpossible to do, please see your instructor at the beginning of next term. He or she will be able to put you in touch with me.

What you all w11l be dolng is an exercise that requires achieving consensus on the part of your group in reaching your decision. You all must be in agreement on the final decision.

The task is not very long and you and your group w111 probably be close to consensus by the end of the 30 minute time period. Your group discussion w11l be tape-recorded but no one will be watching your group while you are working on the task. With the exception of one minute checks on the recording process, no one will be listening to your discussion either. The tapes w111 be coded by numbers so that you will remain anonymous.

Consensus demands participation by all group members, not only one or two or. three people in your group. If your group should arrive at consensus in less than 5 to 10 minutes, that indicates to me that the decision was probably not group consensus at all but a decision pushed through by one or two members. If this should happen, I will have to reschedule your group. Your final decision should reflect the 
criteria as well as being a logical, thoughtful one, the product of all members contributions. Group consensus takes time to achieve and I.personally prefer that each and every member of your group be provided with the maximum opportunity to contribute something to your group decision.

I hope you enjoy the task, which incidentally is specifically designed to encourage discussion among all your group members. Thank you and please begin.............. (by turning the page) 


\section{APPENDIX B}

\section{RELATIVELY AMBIGUOUS TASK}

Your Task: Achieve consensus as to the rankings of the five people in this story.

The Story:

Five shipwrecked people are cast upon two islands. They are close together and in plain sight of each other, but the narrow strait that separates them teems with sharks. Swimming is plainly impossible.

Upon arrival, Mister B sets about gathering up all the wood on Island One. Miss C goes to him and says: "Let me make a raft of your wood so that I can cross over and join Mister D. He and I are engaged and hope to be married". Mister B looks at Miss C and says: "Sure you can make a raft if you spend the night with me." "Beast", shrieks Miss C, appalled. "I could never do that." "Okay," gruffs Mister B, "swim."

In despair Miss $C$ approaches Mister A. He is inspecting grains of sand. "Please sir would you try to persuade Mister B to make me a raft of your wood so that I can cross over and foin Mister D. I love him and want to be with him." Mister A shakes his head. "My dear child," he says, "I am trying to find a crystal so that I can make a radio, communicate with the world, and get us all rescued. Do you really expect me to stop that to help solve your petty personal problems?"

Distraught, Miss $C$ returns to $B$ and accepts his terms. Next 
morning as good as his word, B makes a raft. Miss C crosses safely to Island Two. She runs to D crying, "Darling, I'm here." "So what?" snarls D. "I don't want anything more to do with you. I never knew you were that kind of girl."

Shaken, Miss C turns back to the beach, clearly resolved to feed herself to the sharks. Just as she is about to plunge in, a hand grasps her firmly by the hair. It is Mister $E$. "Don't," he says, "I saw what you did too, but I think I know why you did it and it's a fine, noble thing. I've been hoping all my life to find someone capable of such a selfless act, and now I found her. W11l you marry me?"

Miss C accepts. Rescue is soon at hand. Miss C and Mister E are married by the captain of the rescue ship, and all the castaways return to clvilization and live as happily as possible ever after. Now, 11st the castaways in the order that you and all members of your group agree on from "like the most" to "like the least". Be sure to give the reasons for your list and your final decision. I should like to have one completed list back from each group listing rank-order and reasons for the rank. Remember, all of you must be in agreement as to the final list.

1. Like Most

2.

3 .

4 .

5. Like Least 


\section{APPENDIX C}

\section{RELATIVELY UNAMBIGUOUS TASK}

Your Task: Acheive consensus as to the rankings of the following items. The Story:

You are a member of a space crew originally scheduled to rendezvous with a mother ship on the lighted surface of the moon. Due to mechanical difficulties, however, your ship was forced to land at a spot some 200 miles from the rendezvous point. During landing, much of the equipment aboard was damaged, and since survival depends on reaching the mother ship, the most critical items available must be chosen for the 200-mile trip. Below are listed the fifteen items left intact and undamaged after landing. Your task is to rank order them in terms of their importance to your crew in allowing them to reach the rendezvous point. Place the number 1 by the most important item, the number 2 by the second most important item, and so on, through number 15, the least important. All members in your group must be in agreement as to the ranking. Your answers will be compared to the answers given by NASA at the end of this exercise.

The 15 items:

Box of matches

Food Concentrate

50 feet of nylon rope

Parachute silk

Portable heating unit 
Two .45 callber p1stols

One case dehydrated Pet milk

Two 100-pound tanks of oxygen

Stellar map (of the moon's constellation)

Life raft

Magnet1c compass

5 gallons water

S1gna1 flares

First-aid k1t containing injection needles

Solar-powered FM receiver-transmitter 
APPENDIX D

DIRECTIONS TO CODERS

To: Karla, Mark, Denny

From: Chris

Regarding: The procedure for coding data.

Before I begin with a description of what you are supposed to do, I would like to thank the three of you for giving me part of your valuable time to help me with this research. It means a lot to me, and 1t's sure nice to have such neat friends. I'm not at all sure if such "pleasantries" belong In an introduction to research, but 1t's my study and I'll put them in if I so desire. Thanks a lot for your help.

One important thing to remember is the fact that there are no right or wrong answers in this coding process. All three of you will have Identical coples of the transcripts and I w1ll be checking to see how much agreement there 1s between your respectlve totals, but as far as "rightness" or "wrongness" of the answers, the real test is in how accurate my directions are to you, the coders, in achleving simflar results.

My experiment concerns itself with certain language qualifiers people consciously or subconsclously use in communicating with others. I want you to look for instances when the speaker is excusing, fust1fying, rationalizing, or interpreting for his listeners what he is about to say before he says 1t. Because of the give and take nature of small group discussions (Interruptions, Incomplete thoughts, etc.) 
you may come across some statements which are not complete sentences but nonetheless contain elements of qualification or justification on the part of the speaker, modifying what he is about to say. Score these phrases, whether they occur within a complete sentence or are fragments of a sentence which the speaker never completed due to interruption by others. Examples of such a statement or phrase might include: "You're not going to like this, but....", or "I'm not really sure of this....", or "Off the top of my head I'd say....", or "Now be sure not to take this the wrong way.....", or "I don't want you to think....", or "It goes without saying.....", or "I'd venture to guess that....", or "Since I've spent 5 years studying...." These are just a few examples of the variety of phrases I'd like you to be sensitive to when you are reading over the transcripts. IMPORTANT REMINDER: Discount filler words such as "yeah", "but", "if", "uh-uh", "you know", "I mean", etc., when they appear alone and not in the context of a phrase or sentence. All the phrases I want you to score should Include at least one verb or verb form.

Change of speakers is denoted by a series of......... In the transcript. What I would like you to do is:

1. Read each transcript completely.

2. A series of..... Indicates a change in speakers. When you see this, read the next general thought units or fragments and see if the speaker uses any words or statements which qualify in some way the speaker's intention in expressing that idea. (See examples of phrases of this type above.) When you find such a qualifier (whether completed or fragmented), underline the phrase with the yellow highlighter I 
have enclosed. (An example may be: "Since I favor women's 11b, I would choose Miss C for top rank." You would under11ne "Since I favor women's $11 \mathrm{~b}$ " In ye11ow. The speaker in this instance is justifying the cholce.) Then go to the next..... and so forth. At the end of each section, total the number of phrases you have underlined for that section and write the number at the bottom of the paper.

FINAL NOTE: Perhaps an easier way of looking at this is to look at each phrase or statement and to see what the main Idea is (In the case of Interrupted statements, what the maln Idea might have been if the speaker had not been interrupted) and then re-read the statement and see If there are any phrases used that would Indicate to you that the speaker is fustifylng, apologizing for, interpreting, or qualffying his reasons for making the statement. If there are any of these phrases, underline them in yellow.

Thank-you and have fun:!:!: 